\author{
بررسى شاخصهاى رشدى و ويزّى هاى كيفى هيبريدهاى ذرت علوفهاى در \\ تاريخ كاشتهاى مختلف در ورامين \\ هدايتالله كريمزاده سورشجانى'، محمودرضا تدين ץ"، مرتضى شلالوندّ و يحيى فردى

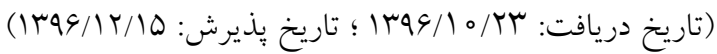

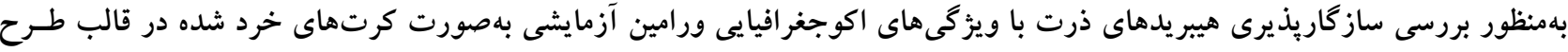

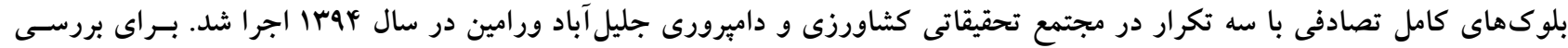

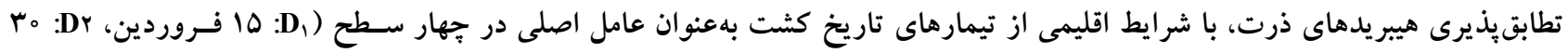

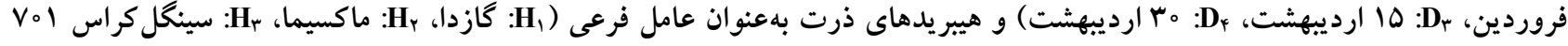

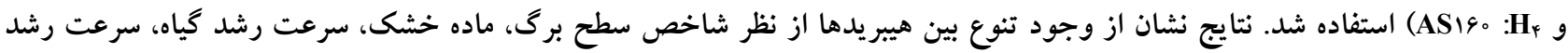

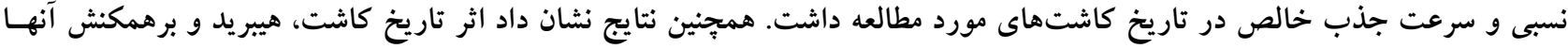

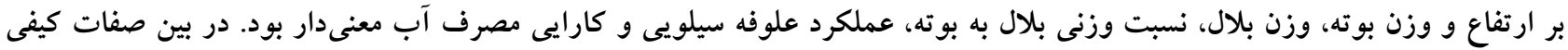

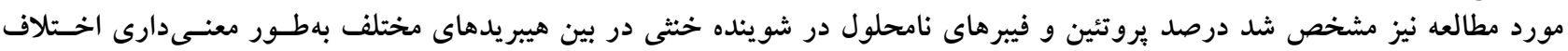

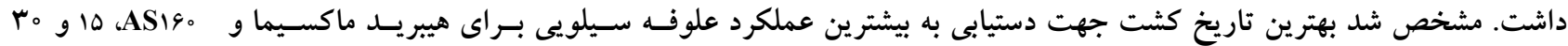

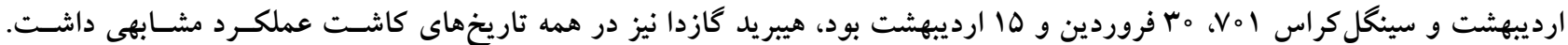

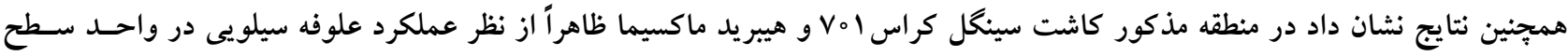

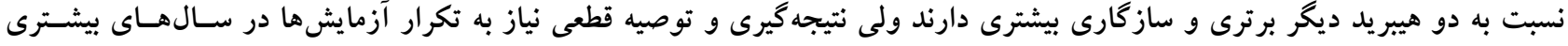

وازههاى كليدى: صفات رشد، يروتئين، كارايى مصرف آب، تاريخ كاشت، عملكرد علوفه

ا. يُزوهشخر فيزيولوزى گياهان زراعى، مركز تحقيقات و نوآورى سازمان اتكا، تهران

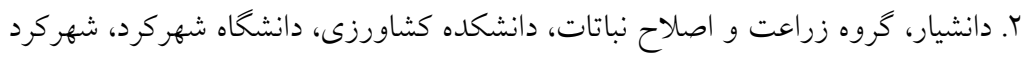

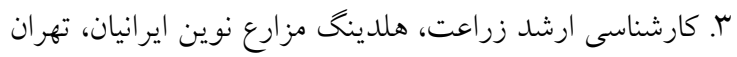

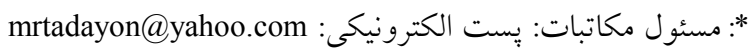


اثـر فاصـله رديـف و تاريخ كشت بـر عملكـرد سـه هيبريسـ

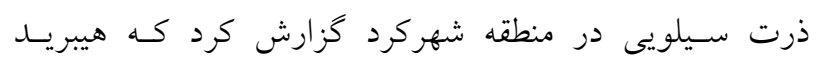

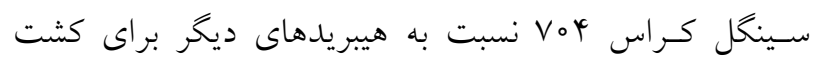

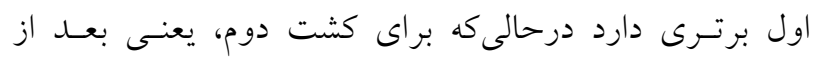

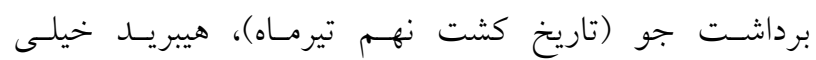

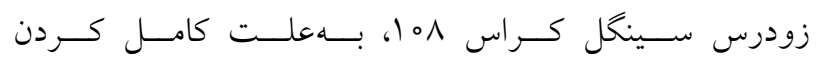
مراحسل فنولوزيكى قبل از رسيدن سرماى شهريور مناسبتر

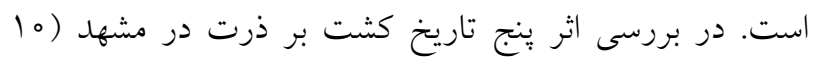

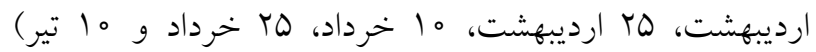

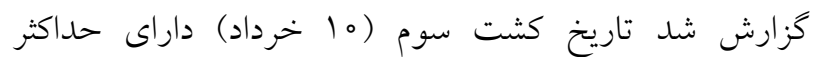
عملكرد بود (10) تعيين تاريخ كشت بهينه هر رقم در هر منطقه از اولين اولويتهاى مديريت زراعى در هر منطقه است. از آنجا كه تمركز داميرورىهاى صنعتى در منطقه ورامين بهعلت مجاورت با تهران رو به كسترش است، كشاورزان به كشت ذرت علوفهاى تمايل زيادى نشان مىدهند. در اين راستا تعيين هيبريدهايى از ذرت كه سازكارى بالايى با شرايط اكوجغرافيايى

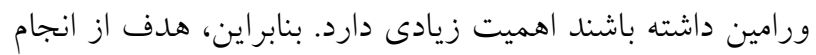

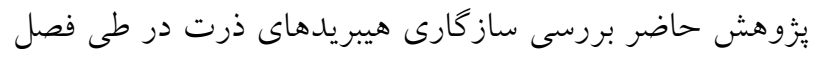

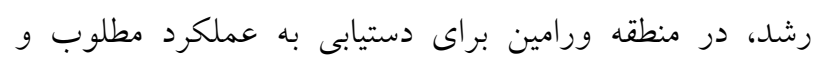
توليد با راندمان بالا بوده است. ورني

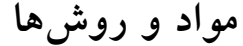
بلممنظور بررسى سازگارى هيبريدهاى ذرت در منطقه ورامين

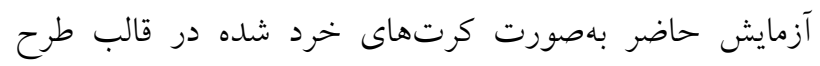
بلوكهاى كامل تصادفى با سه تكرار در مجتمع تحقيقاتى

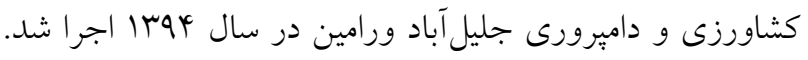
براى بررسى سازگارى هيبريدها از تيمار تاريخ كشت بهعنوان

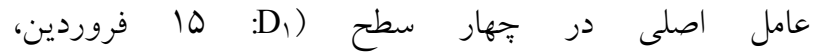
و هيبريدهاى ذرت بهعنوان عامل فرعى (H: كازدا،

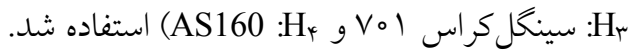

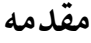

ذرت بهدليل توليد علوفه بالا در واحسـ سطح، كيفيت بالاى علوفه

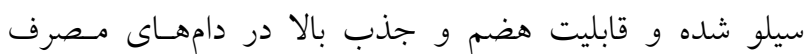
كننده در رده يكى از بهترين كياهان علوفهاى قرار دارد (11). با فابل توجه به اهميت و استفاده روزافزون از ذرت علوفهاى در صنعت لهائ

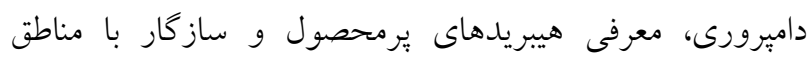
مختلف و تعيين نيازهاى بهزراعى آنها، بهمنظور دستيابى به توليد بهينه هيبريدها در مناطق مختلف از اهداف مهم بهشمار مىرود. براى بررسى سازكارى ارقام به شرايط اكوجغرافيايى در هر هرئس

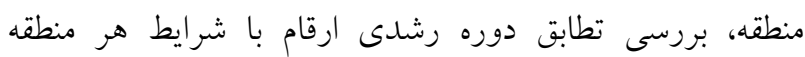

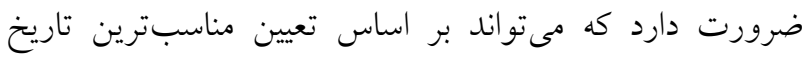
كاشت، انجام يذيرد زيرا باعث استفاده حداكثرى از منابع موجود ماند

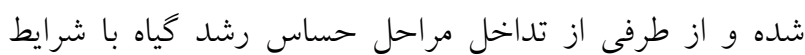

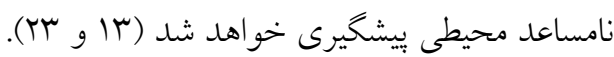
تاريخ كشت بهينه براى مناطق مختلف، براى استفاده از يُانسيل هر رقم در منطقه، از اهميت ويزهاى در برنامهريزى و لئح

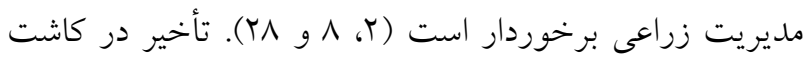
موجب كوتاه شدن دوره رشد شده و توليد مو اد فتوسنتى براى ذخيره در دانه كاهش مىيابد و درنهايت از عملكرد كاسته

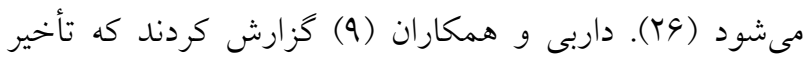
تاريخ كشت در دورگهاى ذرت، موجب كاهش عملكرد دانه

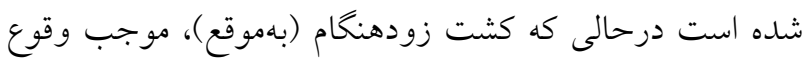

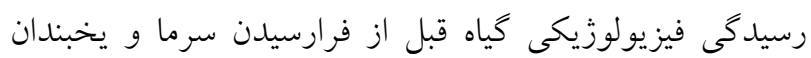

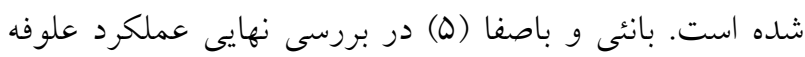

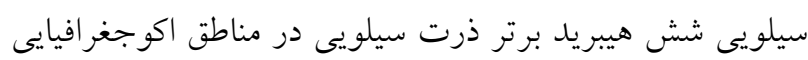

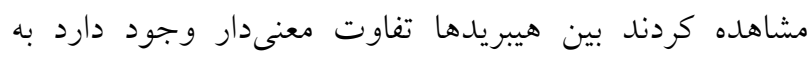

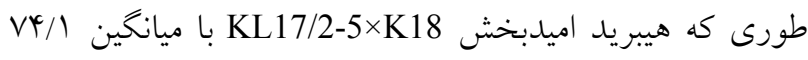
تن علوفه سيلويى در هكتار، بيشترين توليد را در بير بين بين هيبريدهاى مورد مطالعه داشته است. آنها همجنين اظهار داشتيند كه طولانى تر بودن دوره رشدونمو از كشت تا برداشت و كشت هيرت تا ظهور كاكل، مهمترين عوامل در افزايش عملكرد علوفه

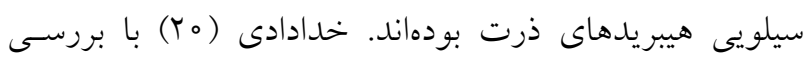




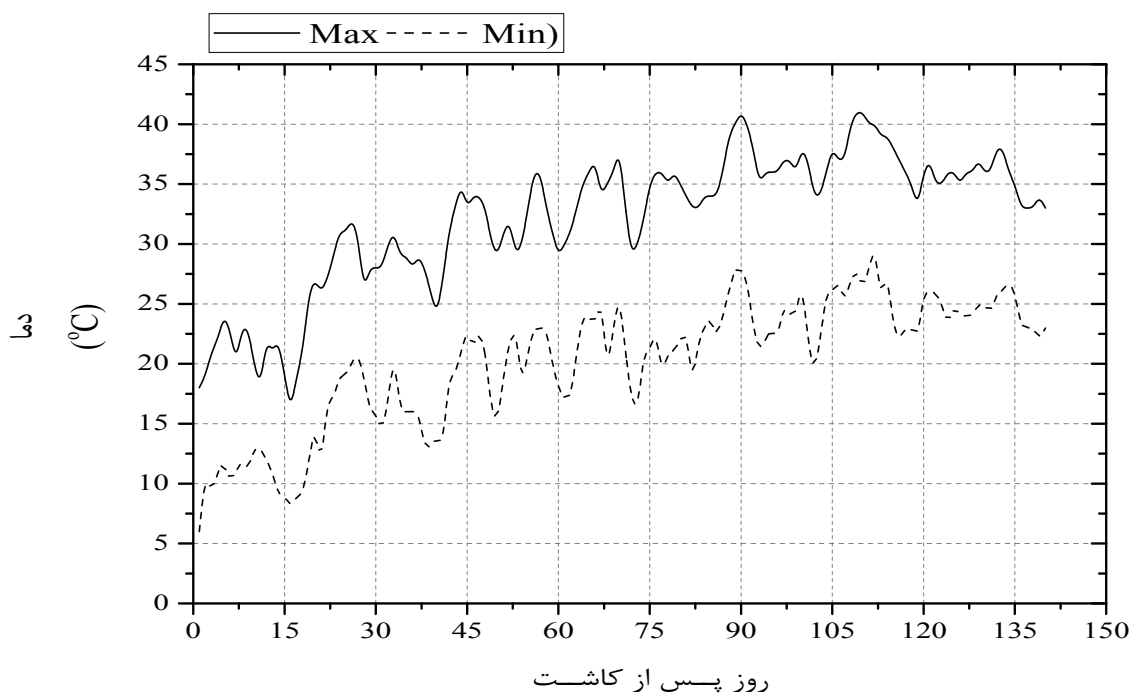

شكل ا. كمينه، بيشينه و متوسط دماى محل انجام آزمايش آثاث

سولفات يتاسيم و ه كيلوكرم در هكتار فسفات از منبع سويرفسفات ترييل همزمان با كاشت) در اختيار كياه قرار كرفت. نتايج آزمون خاك در جدول ا نشان داده شده است. طى فصل رشد وزن خشى و سطح برى بوته از خطوط كشت ميانى در شش مرحله اندازهيرى شد. براى اندازهيرى سطح برگ بهصورت تصادفى از هر كرت سه بوته انتخاب شده و طول و عرض برگهاى آنها اندازهگيرى شد سبس بـ با استفاده از

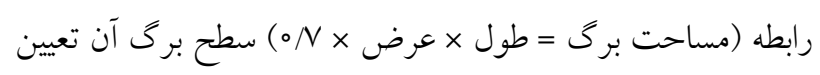
شد (سا) در نهايت با توجه به تراكم بوته در مترمربع (سا بوته در متر مربع)، شاخص سطح برى محاسبه شد. در ابتدا با توجه به ضريب تبين (R2) معادلات، بهترين خط براى روند تجمع ماده خشك برازش داده شد. در آزمايش حاضر معادله سيخموئيد بيشترين همخوانى را با براكنش دادهاى وزن خشك طى فصل

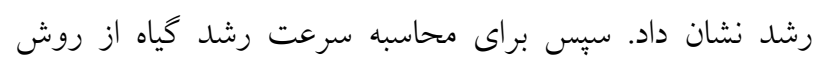
مشتق گيرى از معادله روند تجمع ماده خشك و براى محاسبه

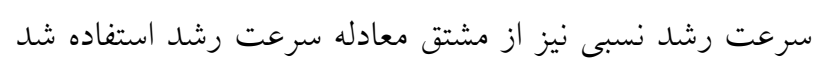
(1). سرعت جذب خالص نيز در هر مرحله از تقسيم سرعت رشد گياه بر شاخص سطح برى (NAR=CGR/LAI) بهدست

بهمنظور اندازهكيرى ميزان علوفه در واحد سطح، در زمان خميرى شدن دانهها برداشت انجام گرفت و وزن بوته، وزن بلال
دماى بيشينه و كمينه محل اجراى آزمايش در طول مدت زمان

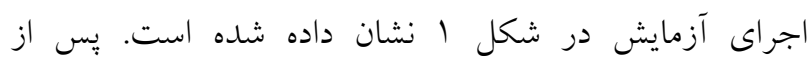
عمليات خاكورزى، بذرهاى هر هيبريد در يشتههايى به فاصله سانتى متر و فواصل بذر روى رديف ه ا سانتىمتر (تراكم سا بوته در متر مربع) كاشته شدند. فاصله بين كرتهاى اصلى دو متر، بين كرتهاى فرعى يك متر و بين بلوكها دو متر بود.

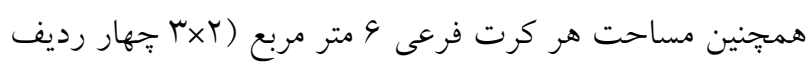
كاشت به طول دو متر) بود. كتترل علفهاى هرز در مراحل اوليه رشد تا زمان بسته به بود شدن سايهانداز ذرت و غالب شدن گياه ذرت بهصورت دستى هرئ انجام شد. يس از كاشت بذور، عمليات آبيارى طبق دور مرسوم

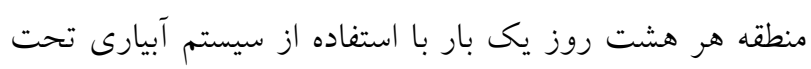
فشار كه خروجى آب توسط كنتور تعيين مىشد، صورت

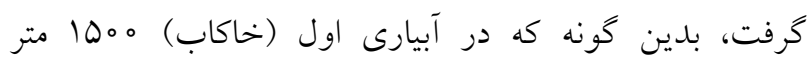
مكعب آب در هكتار مصرف شد و در آبيارىهاى بعدى (10 مرحله) هر مرحله م90متر مكعب در هكتار آب مصرف شد و

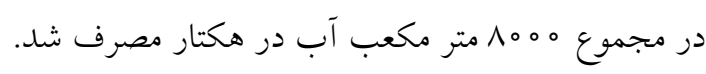

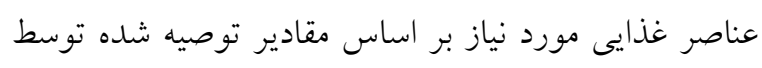

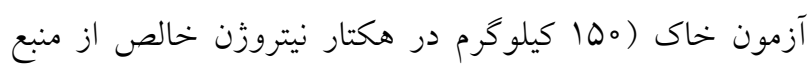
اوره در سه نوبت همزمان با كاشت، وآ ب برگى و ظهور كلآذين نر، يتاسيم بهميزان •ه كيلو گرم در هكتار از منبع 
جدول ا. نتايج آزمون خاك محل اجراى آزمايش

\begin{tabular}{|c|c|c|c|c|c|c|c|c|c|}
\hline مس & آهن & منغنز & روى & يتاسيم & فسفر & نيتروزن & كربن آلى & بֶ هاش & هدايت الكتريكى \\
\hline - /M & $r / r q$ & $N / 11$ & $\circ / \Delta \Delta$ & 149 & $1 \pi / r$ & -/IQT & $0 / 1$ & $V / N 1$ & $0 / 01 T$ \\
\hline
\end{tabular}

بيشترين شاخص سطح برى در سينگل كراس V01 مشاهده شد،

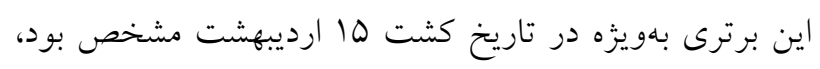

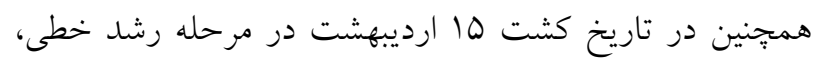

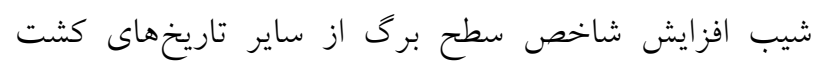

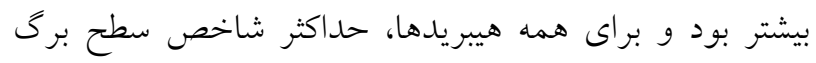

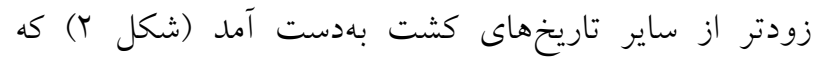

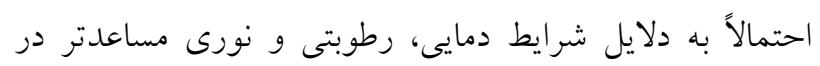

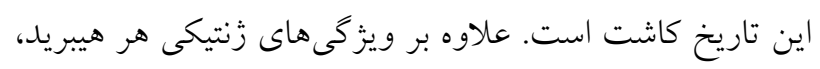

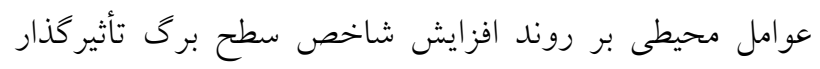

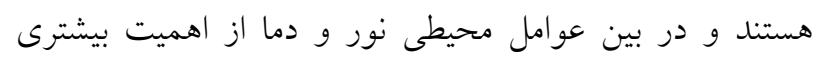

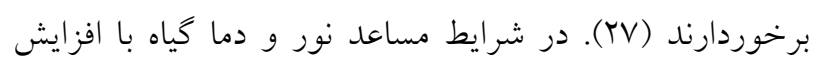

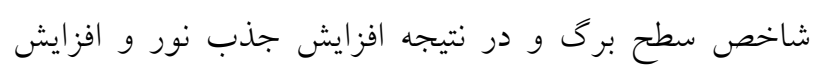

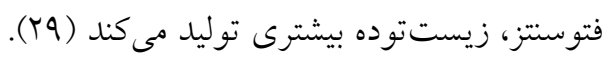

ماده خشك روند تجمع ماده خشك هيبريدهاى ذرت ذرت بهصورت

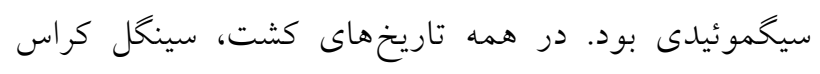

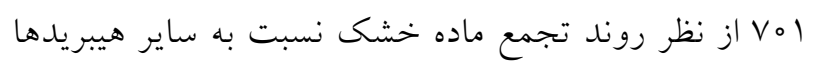
برترى داشت، هرجند اين برترى در تاريخ كشت ماده

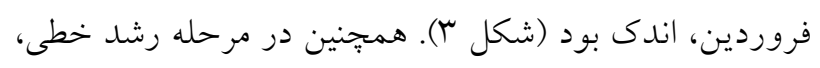

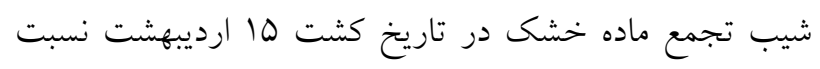

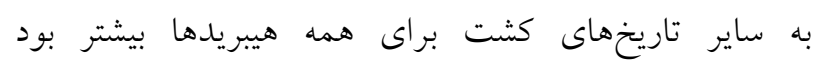

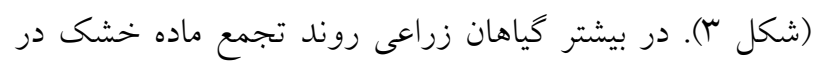

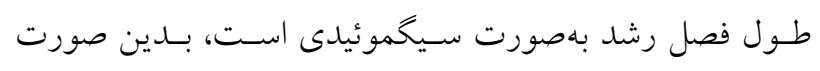

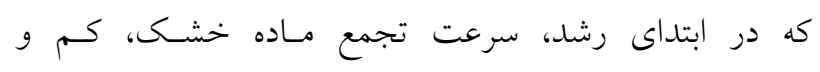

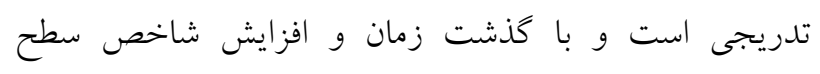

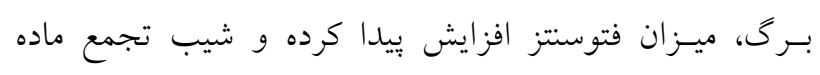

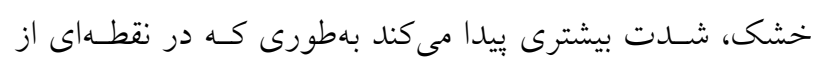

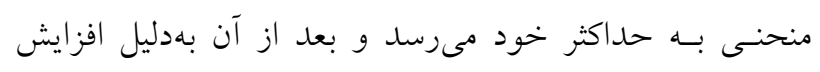

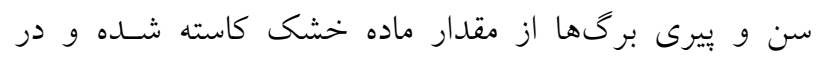

و نسبت وزنى بلال به كل بوته تعيين شد. در زمان برداشت از

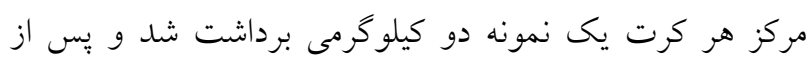

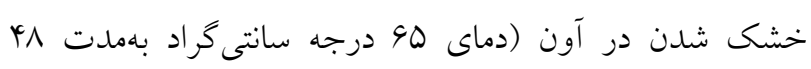

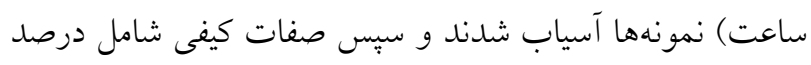

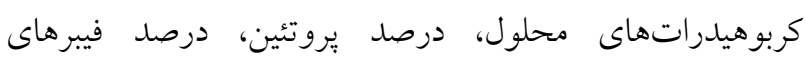

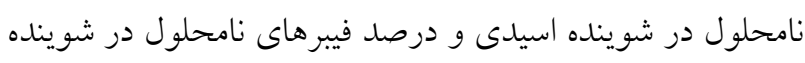

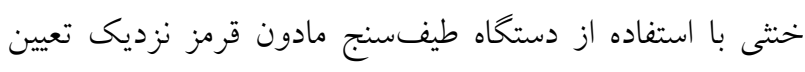
شد. كارايى مصرف آب از تقسيم عملكرد علوفه سيلويى به ميزان

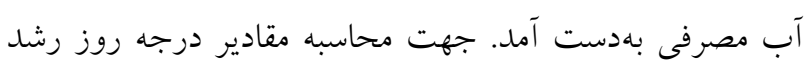
از رابطه (1) استفاده شد.

$\mathrm{GDD}=\sum\left[\left(\frac{\mathrm{T}_{\max }+\mathrm{T}_{\min }}{2}\right)-\mathrm{T}_{\text {base }}\right]$

در رابطه بالا Tد

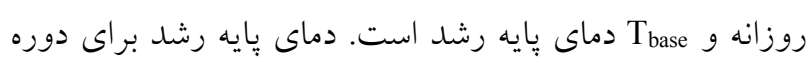

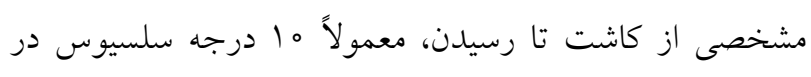

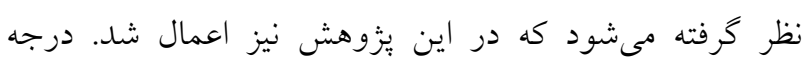

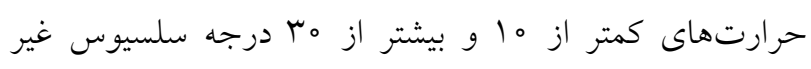

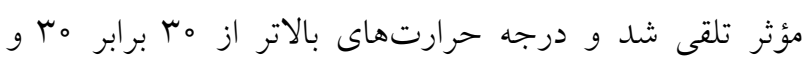

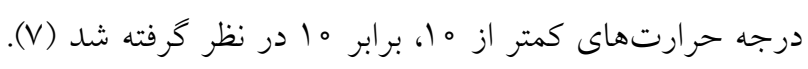

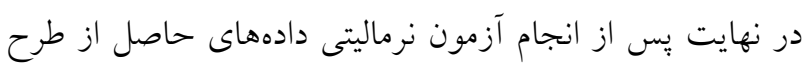

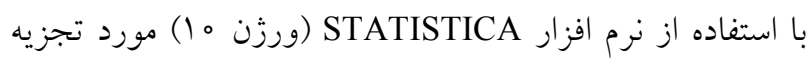

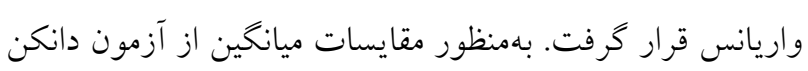
در سطح احتمال بِنج درصد استفاده شد.

\section{نتايج و بحث شاخص سطح برى}

روند افزايش شاخص سطح برى برى هيبريدهاى ذرت مورد بررسى، الخوى سيخموئيدى داشت. در همه تاريخهاى كشت، 


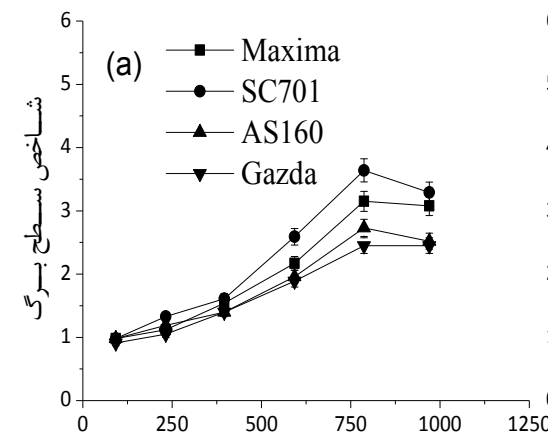

(b)

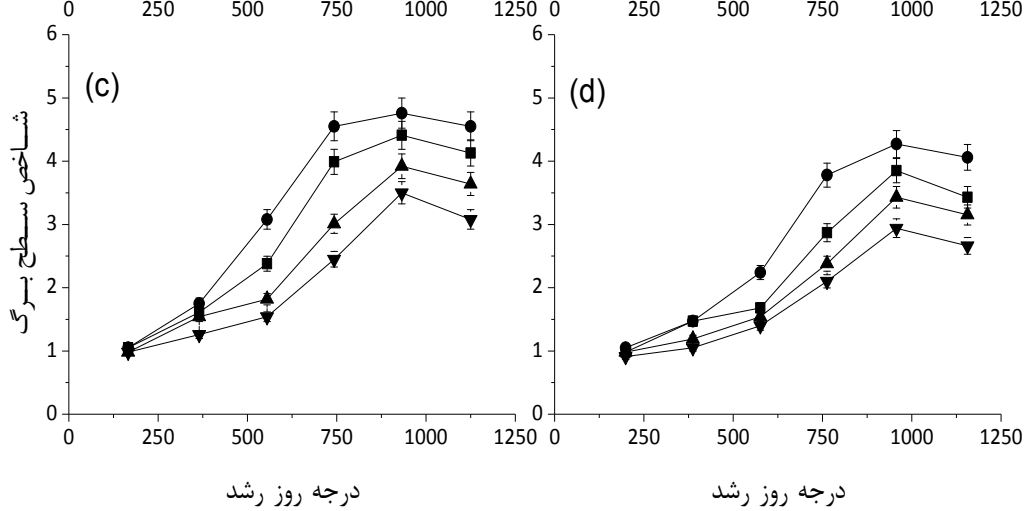

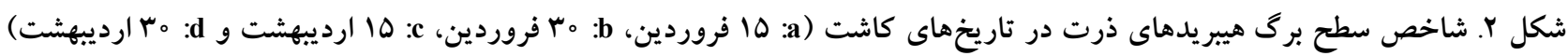
خطوط عمودى (بارها) نشاندهنده خطاى استاندارد هستند.
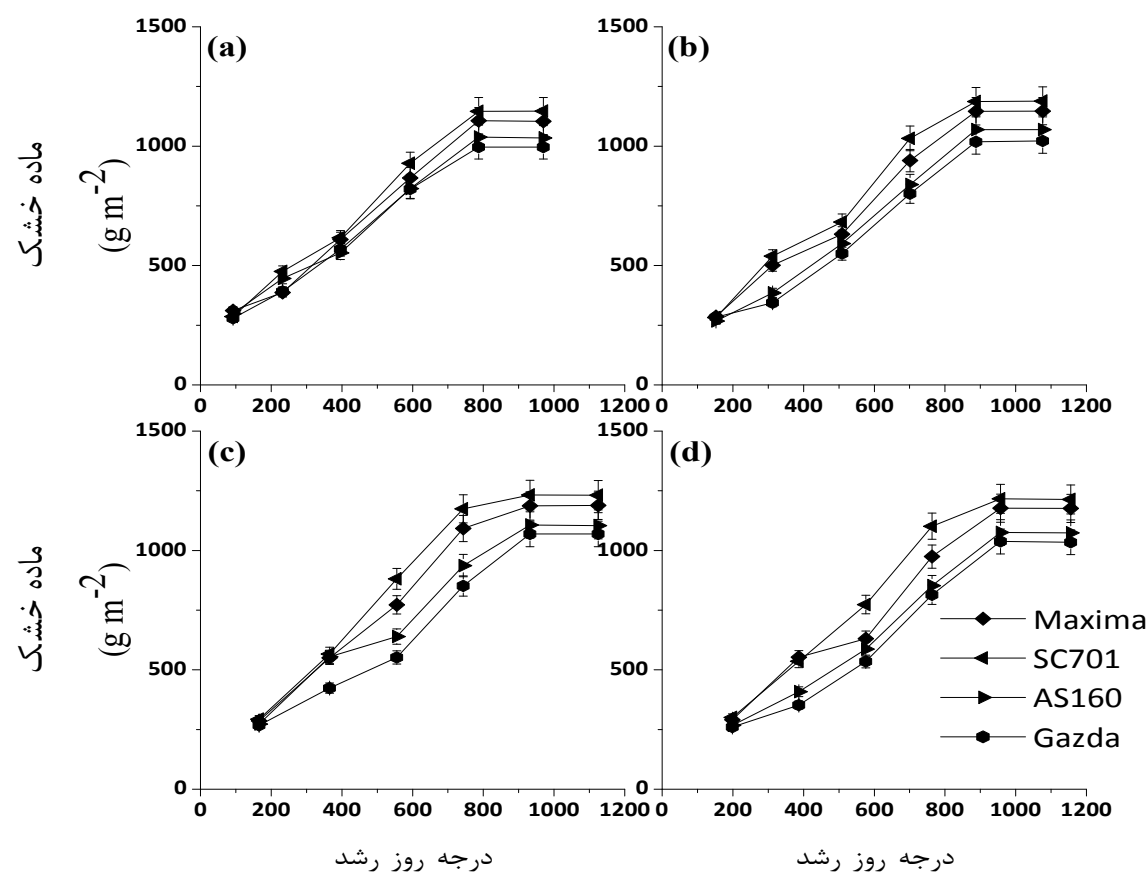

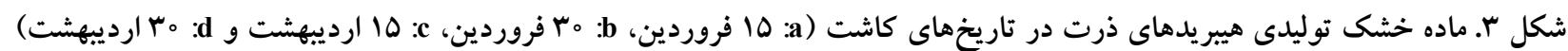
خطوط عمودى (بارها) نشاندهنده خطاى استاندارد هستند. 


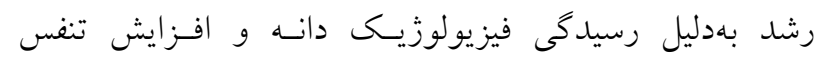

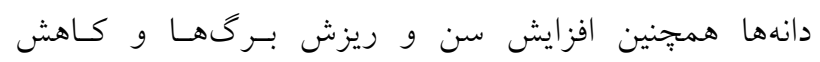

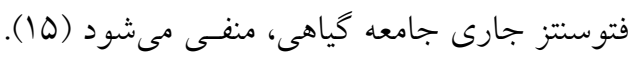

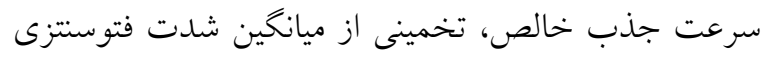

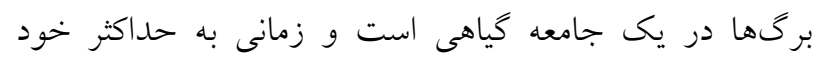
مىرسد كه تمام بركها در معسرض نسور خورشسيد باشند و واين

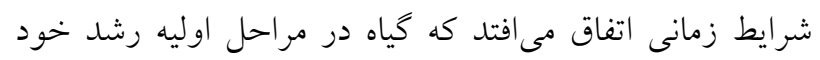

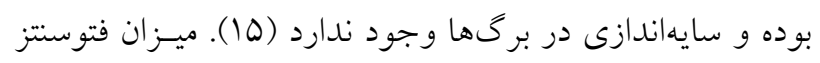
خالص با كذشت زمان ثابت نمىماند و با افزايش سـن كياه

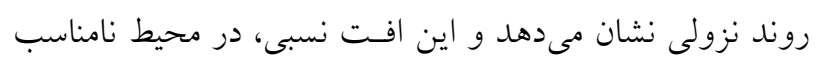

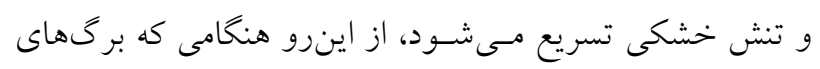

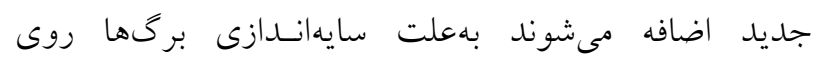

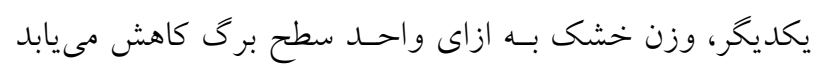

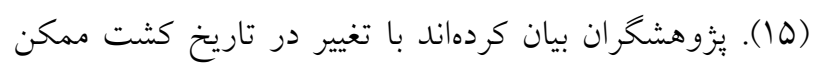

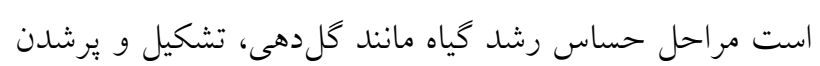

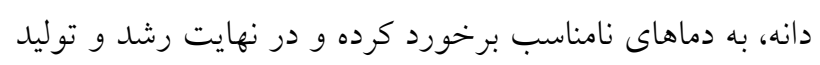

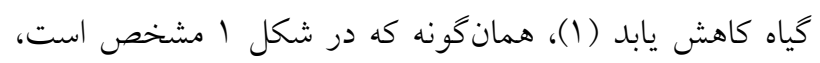

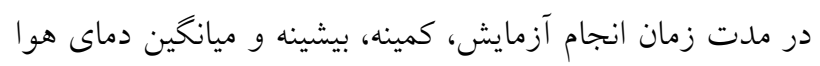
روند افزايشى داشت.

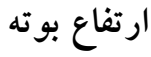

نتايج حاصل از تجزيه واريانس دادهها نشان داد اثر تاريخ كشت، هيبريد و برهمكنش آنها بر ارتفاع بوته معنىدار بود

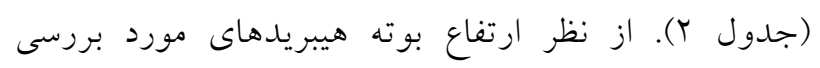

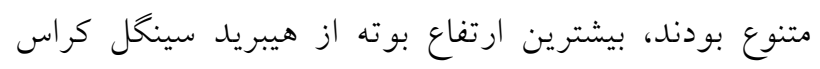

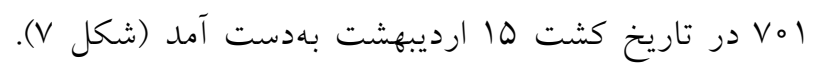

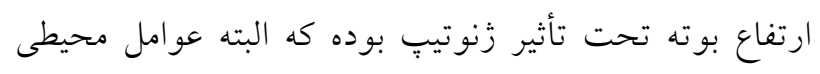

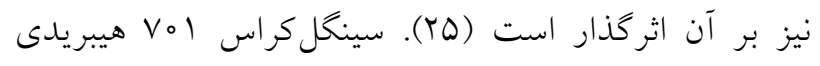

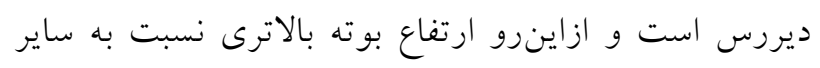

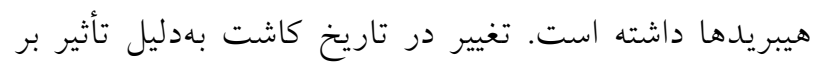

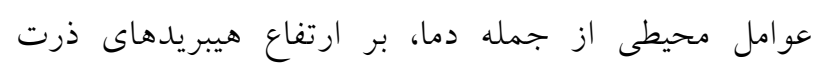
تأثير كذار بوده است.
نهايـت متوقـف مىشود (10). اثر تاريخ كشت بر روند تجمع

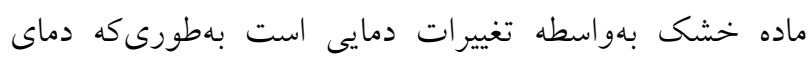

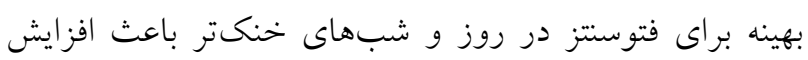
بيشتر تجمع ماده خشى مىشود. در آزمايش حاضر روند تغييرات دما طى دوره انجام آزمايش صعودى بودهد است ماده (شكل 1) تا تاريخ كشت سوم افزايش دما در دامنه دمايى بهينه براى

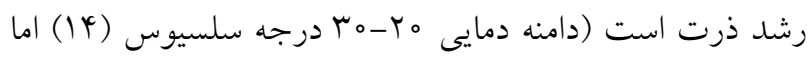

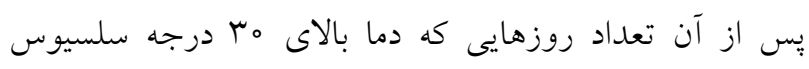

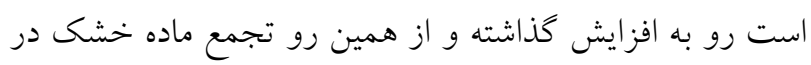
ذرت نيز روند كاهشى نشان داده است.

صفات رشدى همانطور كه در شكل ب مشخص است، سرعت رشد كياه در همه تاريخهاى كاشت و هيبريدهاى مورد بررسى تا اواسط

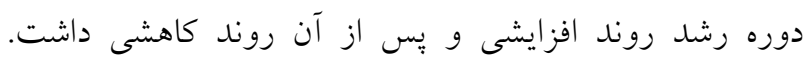

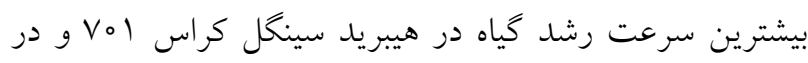

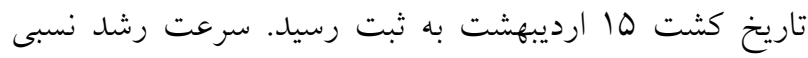
نيز براى همه هيبريدها و تاريخهاى كشت روند نزولى داشت و

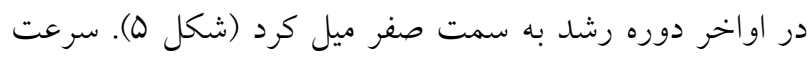

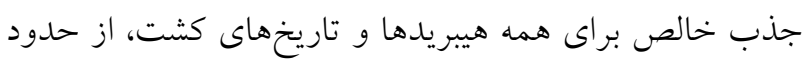

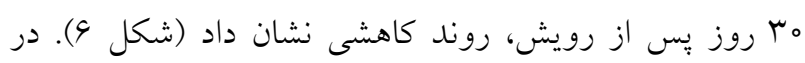

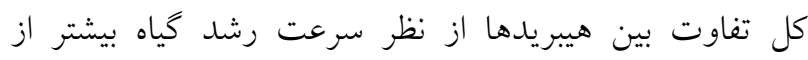
سرعت رشد نسبى و سرعت جذب خالص بود. سرعت رشد

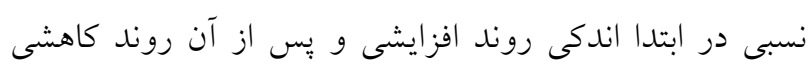

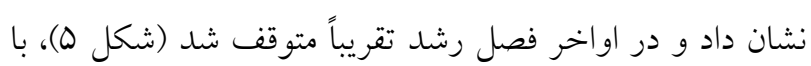
افزايش سن كياه بخشهايى كه به كياه افزوده مىشوند بافتهاى ساختمانى هستند كـهـ از لحساظ متابوليكى فعال نبوده

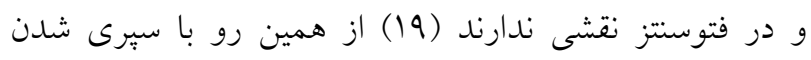

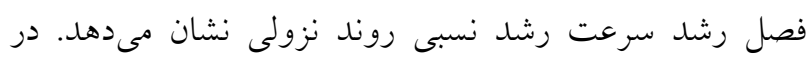

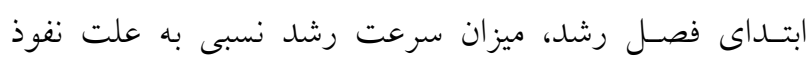

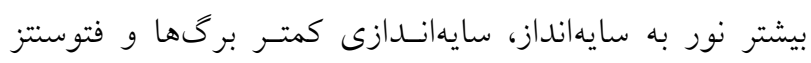

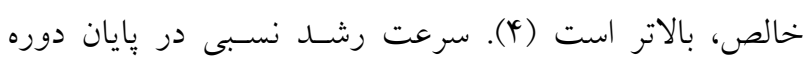




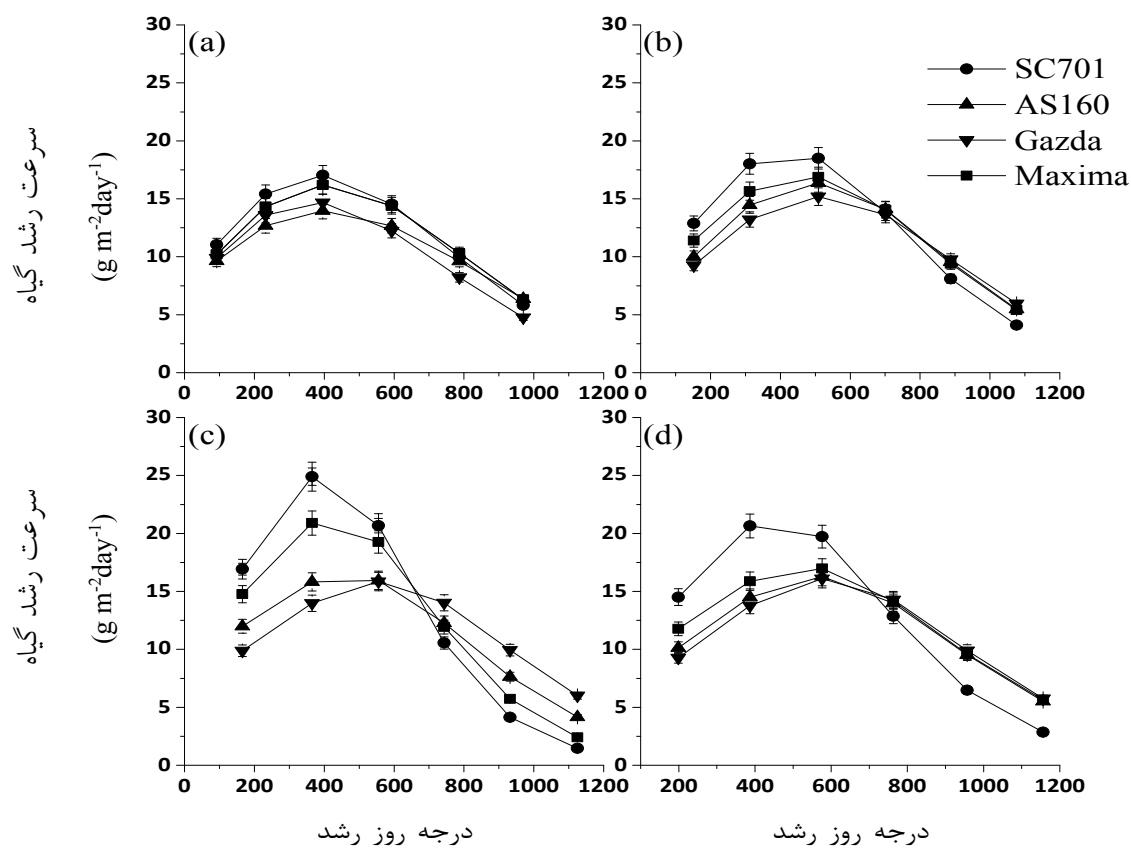

شكل f. سرعت رشد گياه هيبريدهاى ذرت در تاريخ هاى كاشت (a: 10 فروردين، b: مب فروردين، c: 10 ارديبهشت و d: مب ارديبششت) خطوط عمودى (بارها) نشاندهنده خطاى استاندارد هستند.

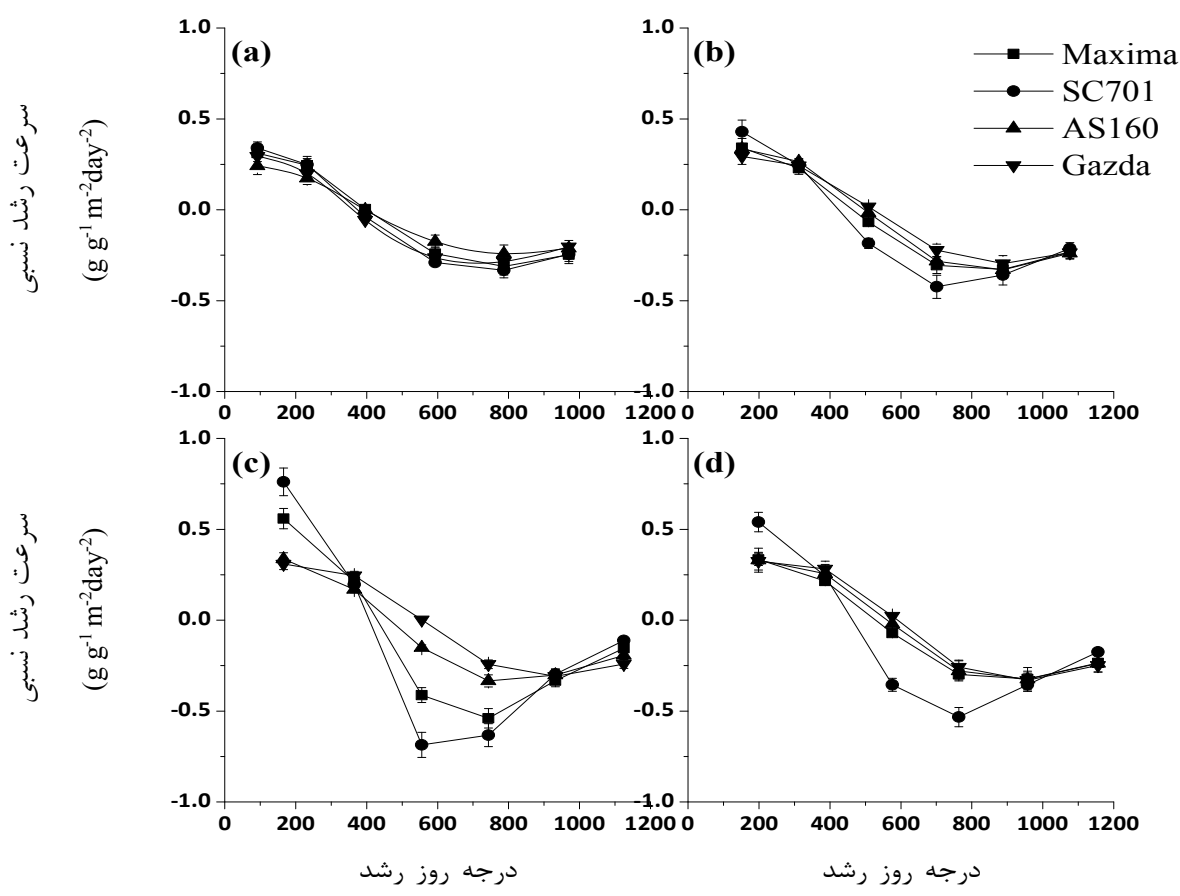

شكل ه. سرعت رشد نسبى هيبريدهاى ذرت در تاريخهاى كاشت (a: $ه$ ( فروردين، b: مب فروردين، c: 10 ارديبهشت و d: مب ارديبهشت) خطوط عمودى (بارها) نشاندهنده خطاى استاندارد هستند. 


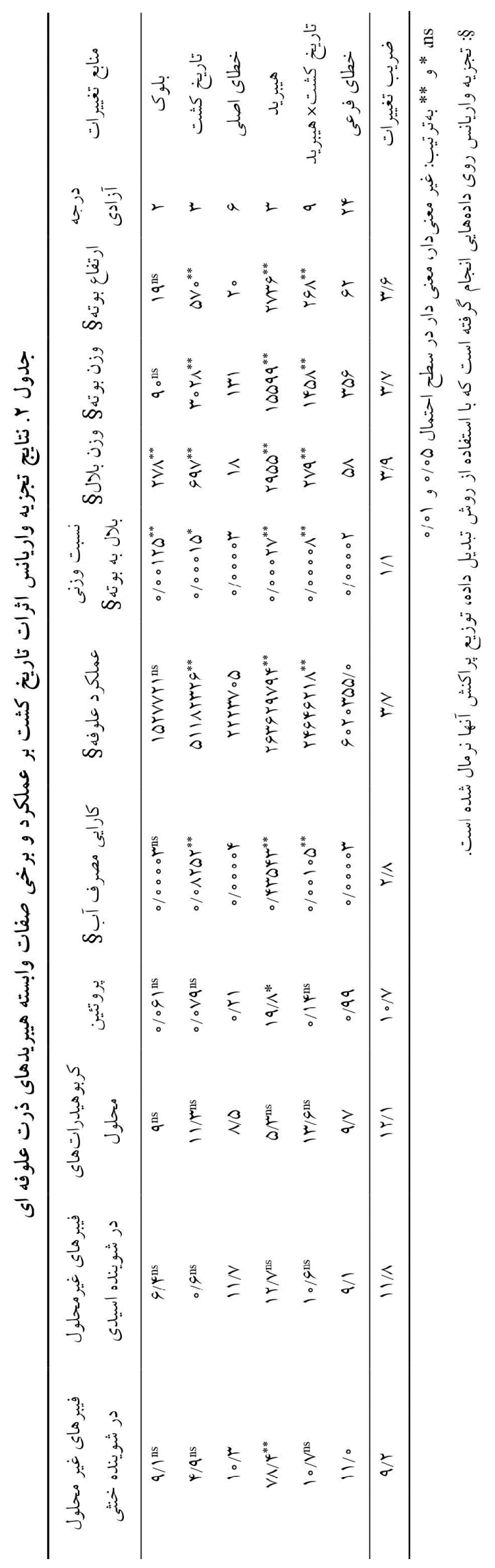



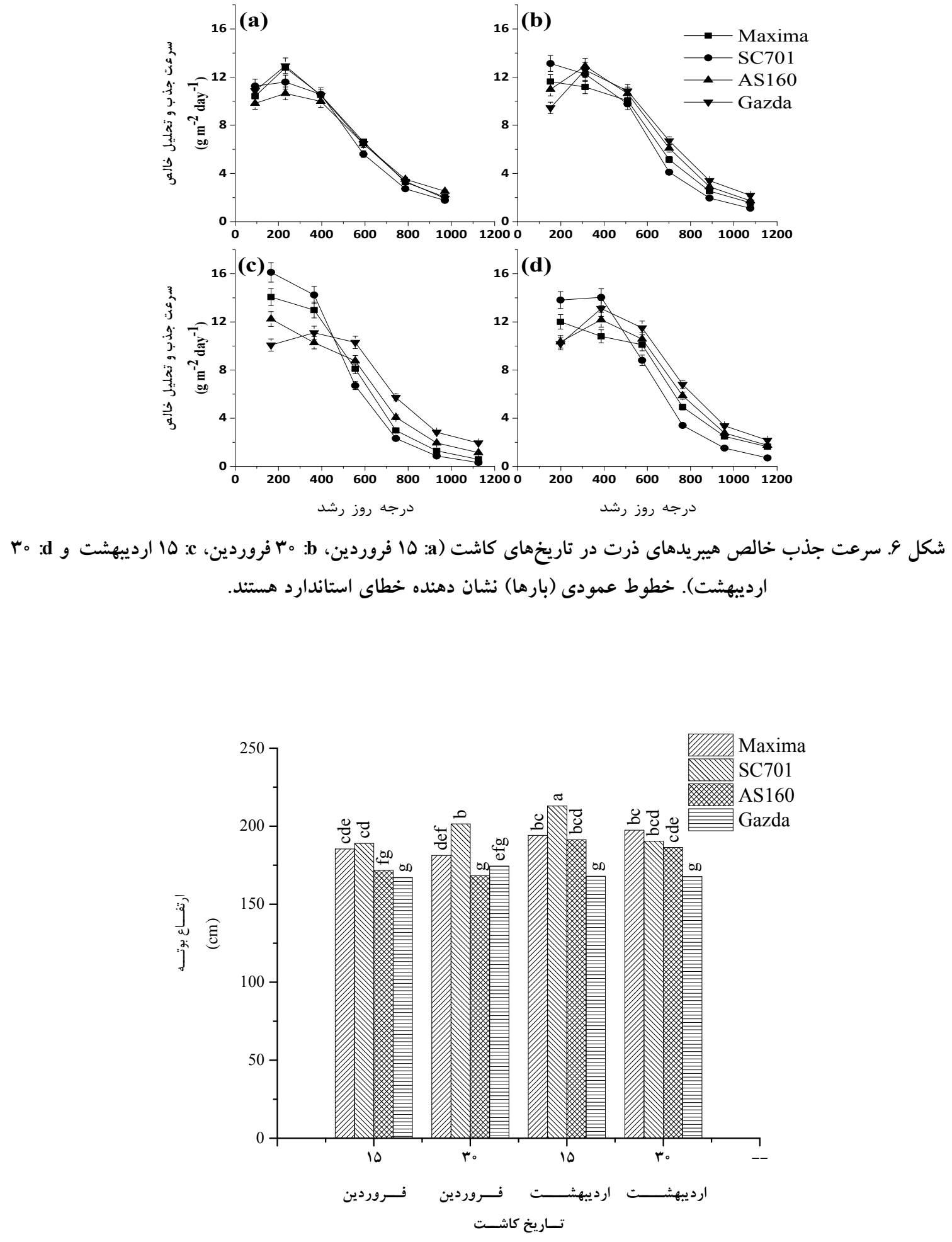

شكل V. ارتفاع بوته هيبريدهاى ذرت در تاريخ كاشتهاى مورد بررسى. ستونهاى داراى حرف مشترك اختلاف معنى دارى در سطح

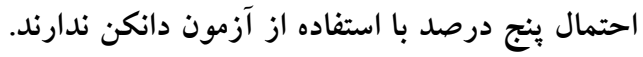


صورتى كه شرايط محيطى از قبيل تنشهاى زيستى و غير زيستى طى دوره رشد كياه رخ ندهند، تركيبات بيوشيميايى كياه

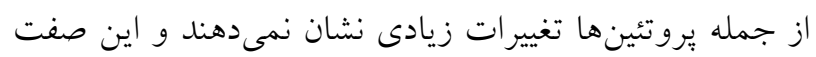

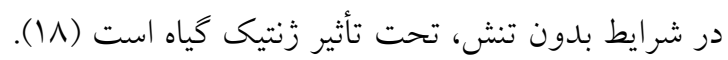

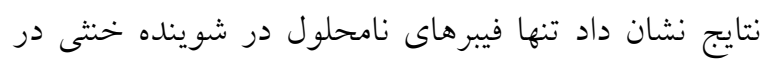
بين هيبريدهاى مورد بررسى تغييرات معنىدارى داشت و و كربوهيدراتهاى محلول در آب و فيبرهاى نامحلول در اسيد

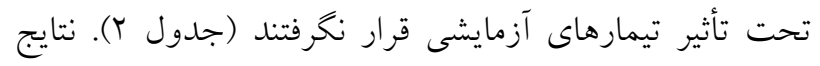

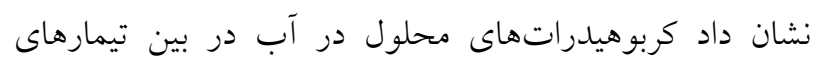

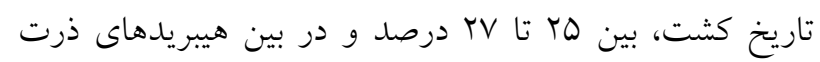
بين TY تا و Y درصد متغير بود. كربوهيدراتهاى محلول كه بئ بخش عمدهاى از كربوهيدراتهاى غير ساختارى را تشكيل

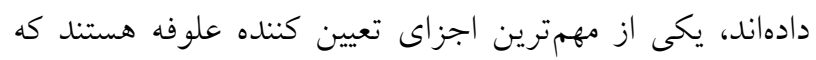
وظيفه آن تهيه انرزى براى ميكرواركانيزمهاى شكمبه دام و دهئ

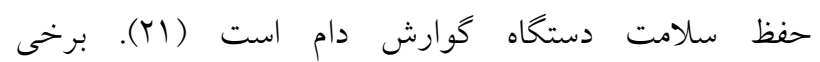

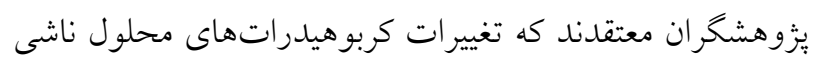

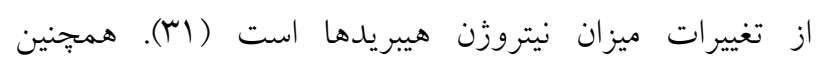

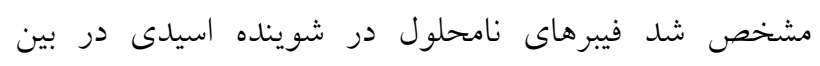

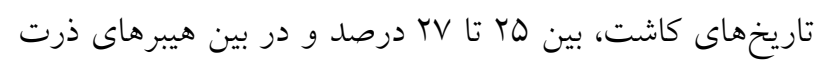

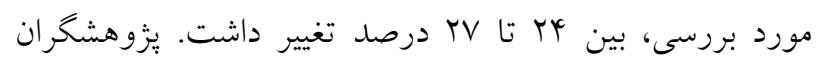
بيان كردند درصد فيبرهاى نامحلول در شوينده اسيدى بهترين شاخص براى بيان ارزش غذايى نسبت به فيبر خام و سلولز

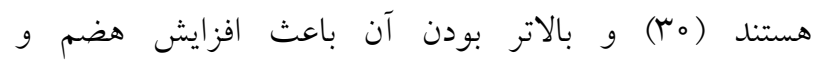

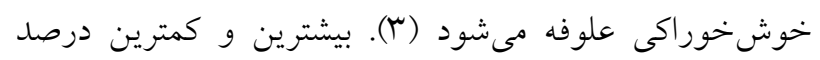
فيبرهاى غير محلول در شوينده خنثى نيز در هيبريدهاى سينگل فئل

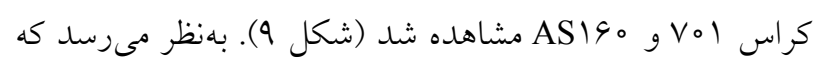

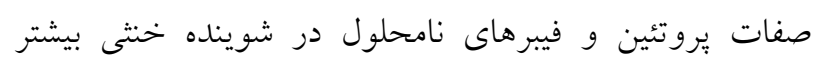

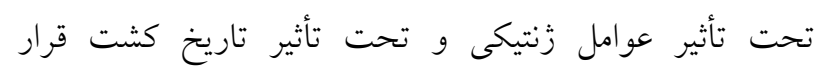

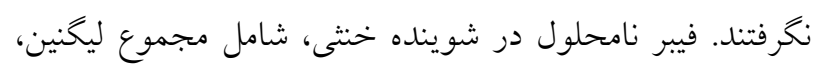

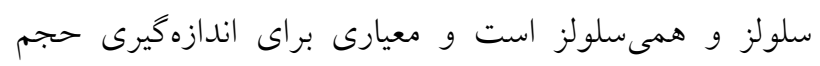

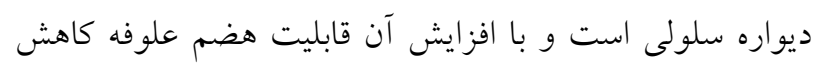

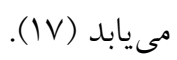

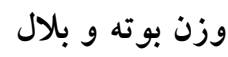
اثر تاريخ كشت، هيبريد و برهمكنش آنها بر وزن بوته، وزن بلال، نسبت وزن بلال به بوته و عملكرد علوفه، معنى دار بود (جدول

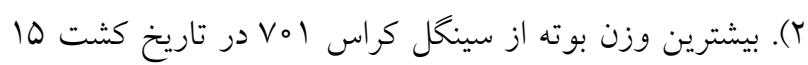

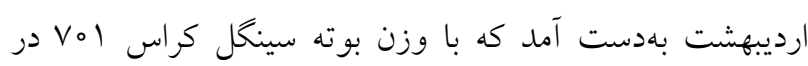

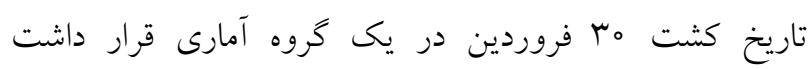

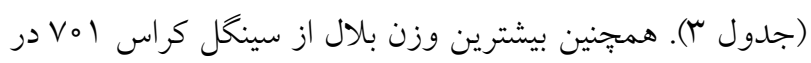

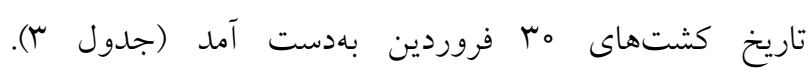
هيبريدهاى مورد بررسى از نظر نسبت وزنى بلال به بوته متنوع

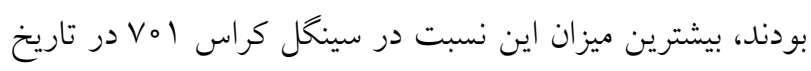
كشت ها ارديبهشت بهدست آمد كه با هيبريد ماكسيما در تاريخ

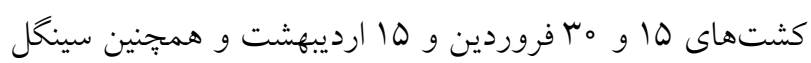
كراس Vol در تاريخ كشت مب فروردين اختلاف معنىدارى

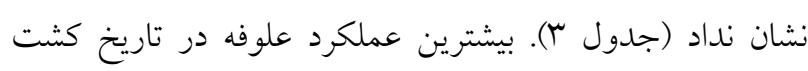

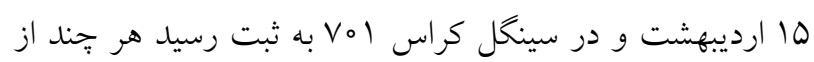
نظر آمارى اختلاف معنىدارى با عملكرد علوفه سينگل كراس

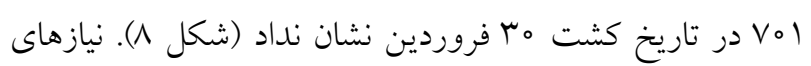

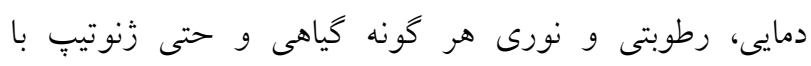
يكديخر متفاوت است (هQ) ازاينرو براى هيبريد ذرت، هر كاه وناه

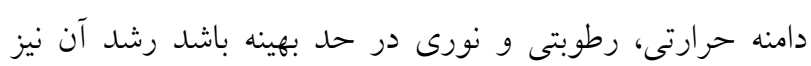

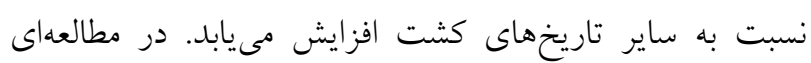
كزارش شده است كه دو تاريخ كاشت اول بهدليل استفاده بيشتر

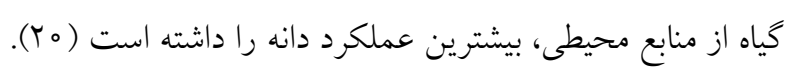

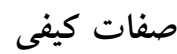

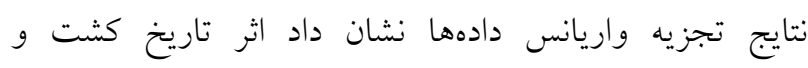
برهمكنش تاريخ كشت × هيبريد بر بروتئين علوفه معنى دار

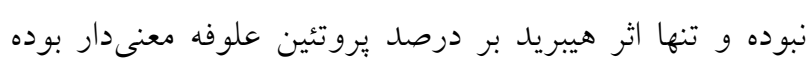

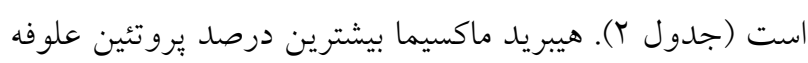

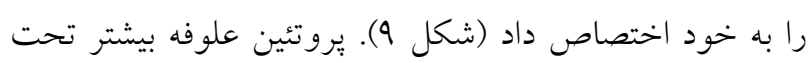

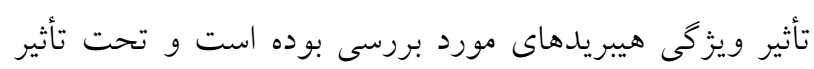

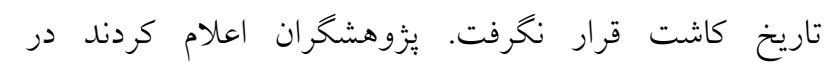


جدول r. نتايج مقايسه ميانگين وزن بوته، وزن بلال، نسبت وزنى بلال به بوته و عملكرد علوفه سيلويى هيبريدهاى ذرت در تاريخهاى كاشت مختلف

\begin{tabular}{|c|c|c|c|c|}
\hline نسب وزن بلال به بوته & وزن بلال (كرم) & وزن بوته (كرم) & هيبريد & تاريخ كشت \\
\hline$r \wedge / V_{\circ} a b c$ & $100 / /^{c d}$ & $r \Delta \wedge / q^{\mathrm{cd}}$ & Maxima & \\
\hline 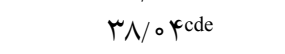 & $10 \% \% c d$ & $r G Y / A^{c d}$ & SCV.1 & ها فروردين \\
\hline$r 4 / 9 \Lambda^{f}$ & $\Lambda \mathrm{V} / \mathrm{G}^{\mathrm{e}}$ & $r \mu / / \Lambda^{e}$ & AS 190 & \\
\hline rV/G Yef & $\Lambda \mathrm{V} / \mathrm{V}^{\mathrm{e}}$ & & Gazda & \\
\hline 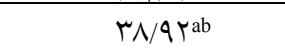 & $q V / 0^{d}$ & $r \Delta \circ / \Delta^{\text {de }}$ & Maxima & \\
\hline$\Gamma \wedge /\left.\Delta\right|^{a b c}$ & $1 \circ \Lambda / 4 b$ & $r \wedge \backslash / Y^{\mathrm{ab}}$ & SCV01 & مب فروردين \\
\hline $\mathrm{rV} /\left.\bar{G}\right|_{\text {de }}$ & $1 \mathrm{~V} / \mathrm{qe}^{\mathrm{e}}$ & e & AS $19 \circ$ & \\
\hline rV/gY de & $9 \circ / \mathrm{ve}^{\mathrm{e}}$ & $r Y Y / 0^{e}$ & Gazda & \\
\hline 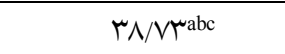 & $1 \circ 4 / \Delta^{b c d}$ & $r q q / V^{b c}$ & Maxima & \\
\hline$r q / Q)^{r a}$ & $11 \mathrm{~V} / \mathrm{\mu}^{\mathrm{a}}$ & $r Q \varphi / 0^{\mathrm{a}}$ & SCV.1 & ه ارديبهشت \\
\hline$r V / q r^{c d e}$ & $1 \circ \circ / /^{c d}$ & $r \& \varphi^{c} / \Delta^{\mathrm{bcd}}$ & AS 19. & \\
\hline${ }^{\mu} / / \varphi_{\text {cde }}$ & $\wedge q / 1^{e}$ & & Gazda & \\
\hline rN/०६cde & $1 \circ \Delta / /^{\mathrm{bc}}$ & TVG/Gbc & Maxima & \\
\hline$r V / \Delta Y^{c d e}$ & $1 \circ \circ / Y^{c d}$ & $Y \& V / 0 \mathrm{bcd}$ & SCV.1 & هץ ارديبهشت \\
\hline 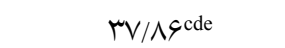 & $Q \wedge / 0^{c d}$ & $r \varphi \% / /^{\mathrm{cd}}$ & AS 19. & \\
\hline r/N//bcd & $M M / q^{e}$ & & Gazda & \\
\hline
\end{tabular}

در هر ستون، ميانخين هاى داراى حرف مشترك اختلاف معنى دارى در سطح احتمال بنج درصد با استفاده از آزمون دانكن ندارند.

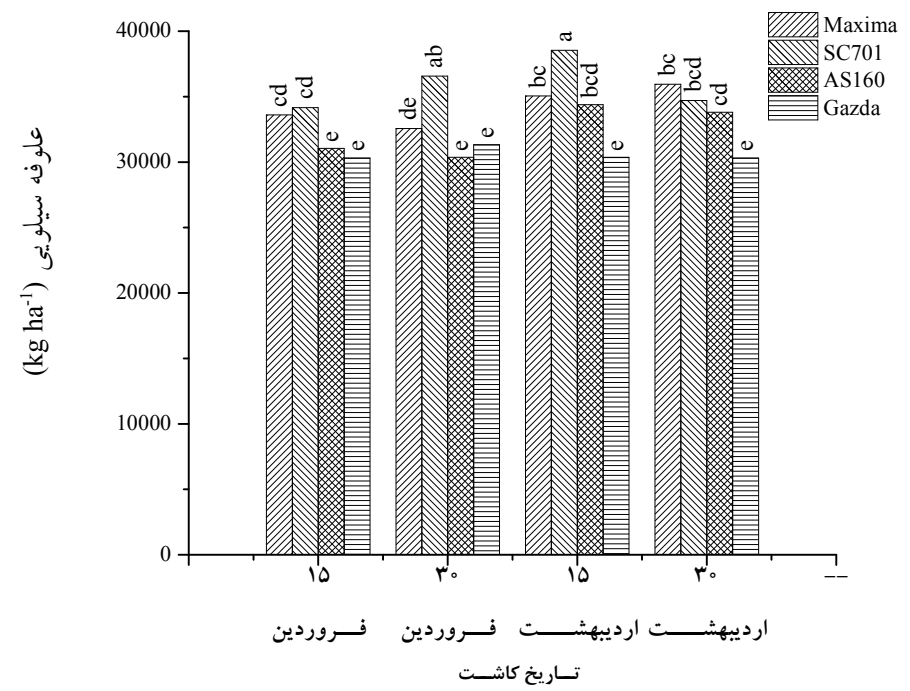

شكل ^^ عملكرد علوفه سيلويى هيبريدهاى ذرت در تاريخ كاشتهاى مورد بررسى. ستونهاى داراى حرف مشترك اختلاف معنىدارى در

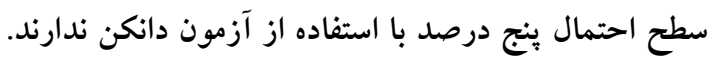

مقايسه با ساير هيبريدهاى مورد بررسى، به ازاى هر واحد آب

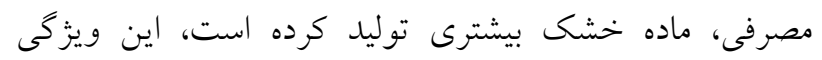

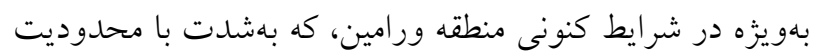

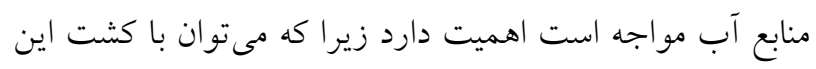
هيبريد، در ازاى آب مصرفى ماده خشك بيشترى توليد كرد

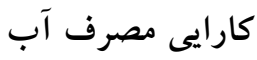
نتايج نشان داد تاريخ كشت، هيبريد و برهمكنش آنها بر كارايى مصرف آب اثر معنىدار داشت (جدول باد ). بيشترين ميزان

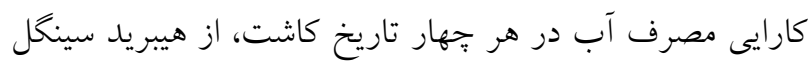

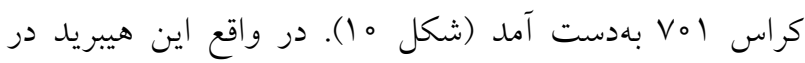



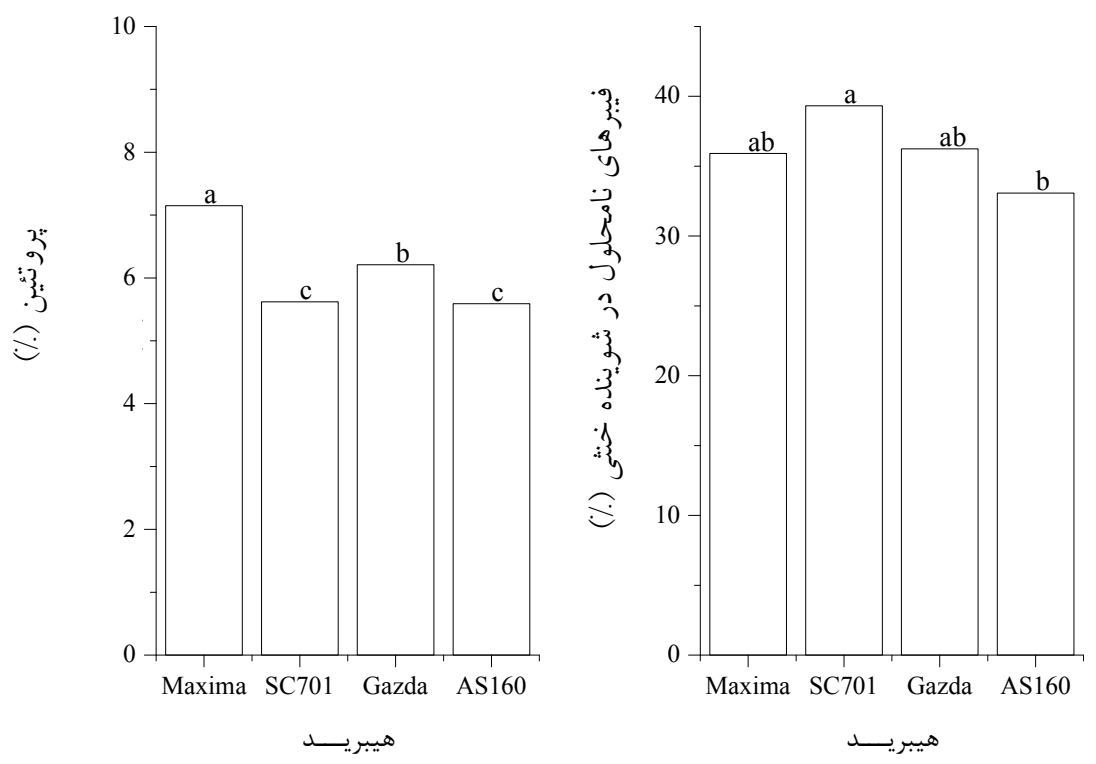

شكل 9.

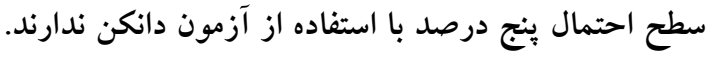

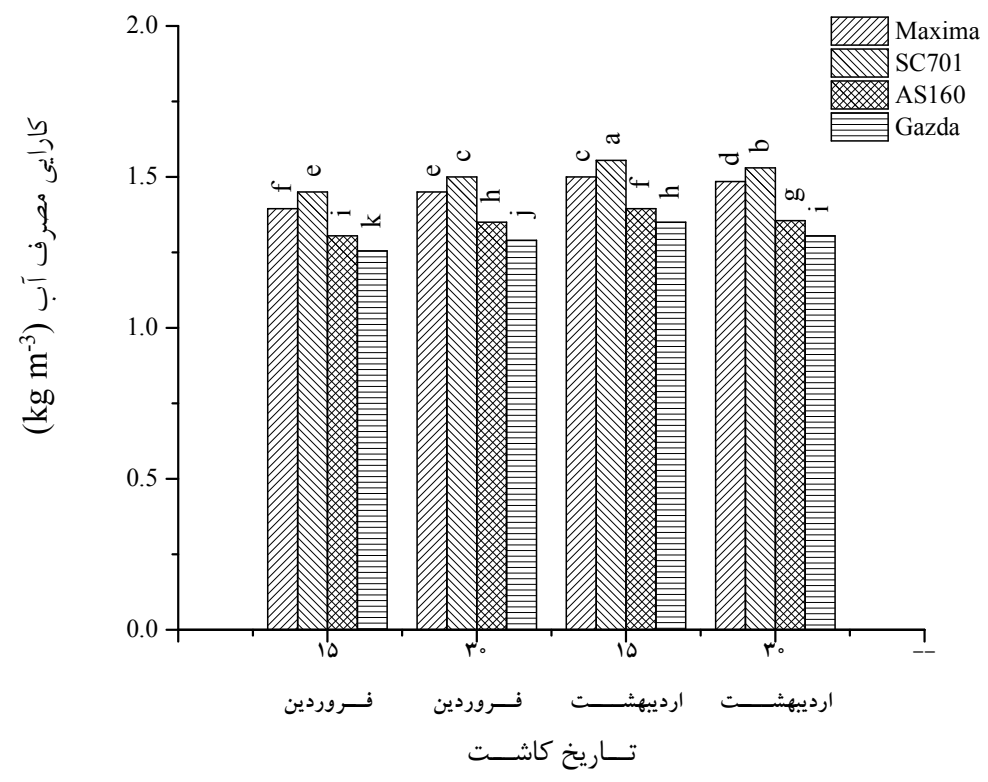

شكل • ا. كارايى مصرف آب هيبريدهاى ذرت در تاريخهاى كاشت مختلف. ستونهاى داراى حرف مشتر اختلاف معنىدارى در سطح احتمال بِنج درصد با استفاده از آزمون دانكن ندارند.

و يا به عبارت ديخر، اين هيبريد بهدليل شاخص سطح برى و دما و رطوبت باعث كارايى مصرف آب بالاتر مىشود (9) و

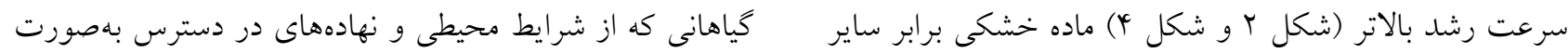

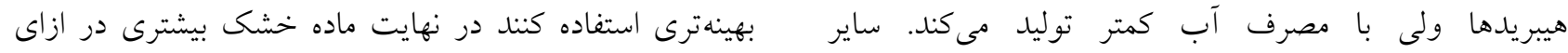
يزوهشكران نيز بيان كردهاند شرايط محيطى بهينه از نظر نور، مصرف ميزان مشخصى آب توليد مى كنند (TQ). 

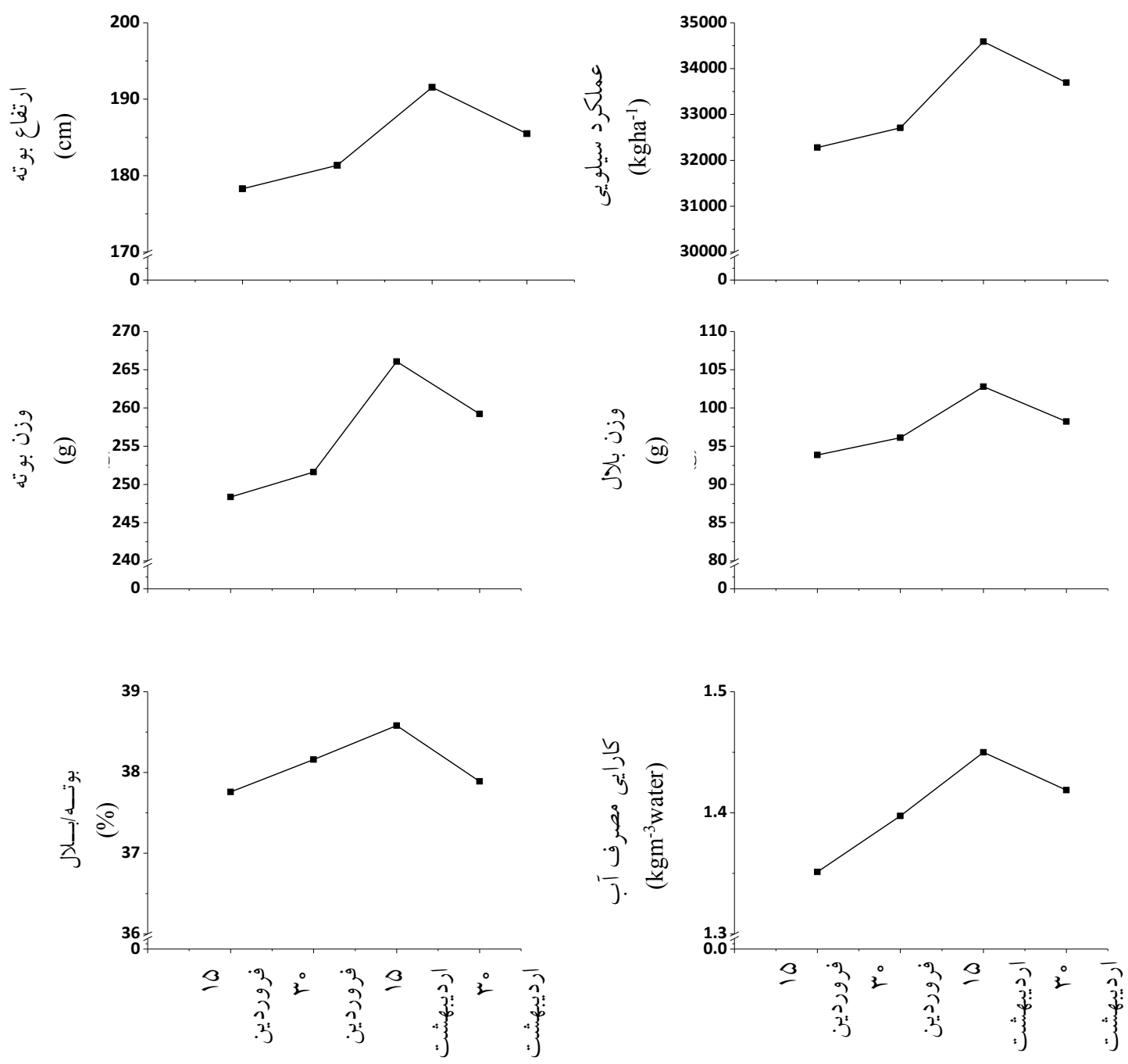

تاريخ كاشت

تاريخ كاشت

شكل ال. ارتفاع بوته، عملكرد سيلويى، وزن بوته، وزن بلال، نسبت وزنى بلال به بوته و كارايى مصرف آب در تاريخهاى كاشت مختلف

خواهد شد (צا، YY). همجنين گزارش شده است كاشت در تاريخ

مناسب باعث دوام سطح برث بالاتر خواهد شد (T M و TY).

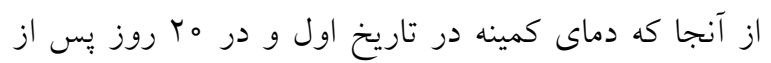

كاشت پايين بوده است (كمتر از ها درجه سانتى گراد) همين

موضوع باعث كاهش سرعت سبز شدن و كند شدن رشد اوليه در اين تاريخ بوده است، از ديخر سو، هيبريدهاى كشت شده در تاريخ كشت جهارم (مب ارديبهشت) نيز در دوره حساس رشد

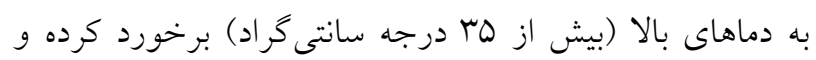
دوره رشدى و نموى آنها كوتاهتر شده و ازاينرو قابليت رسيدن به يتانسيل رشد خود را نداشتهاند، به نظر مىرسد تاريخ مناسب
همانطور كه از نتايج آزمايش (شكل (1) مشخص است ميانخين ارتفاع بوته، عملكرد علوفه سيلويى، متوسط وزن بوته، وزن بلال، نسبت وزنى بلال به بوته و كارايى مصرف آب هيبريدهاى مورد بررسى تا تاريخ كشت سوم (ها ارديبهشت)، روند افزايشى و از بازي آن پِ روند كاهشى داشتند. اين موضوع، به دليل افزايش دما و همزمانى دوره حساس كلدهى هيبريدها با هواى گرم اتفاق افتاده است. كاشت در تاريخ مناسب باعث مىشود كياه از شرايط محيطى (دما، نور و رطوبت) استفاده بهينه كرده و در نتيجه سايهانداز كياه، در مقايسه با تاريخ كشتهاى نامناسب توسعه بيشترى خواهد داشت كه منجر به افزايش شاخص سطح برى 


\section{نتيجه گيرى}

نتايج نشان داد بهترين تاريخ كشت براى دستيابى به بيشترين عملكرد

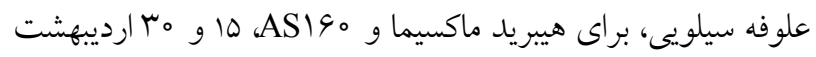

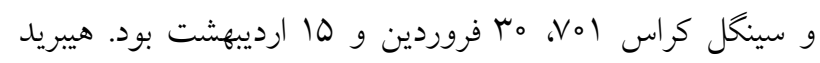
كازدا نيز در همه تاريخهاى كشت از نظر آمارى عملكرد علوفه يكسان و كمتر از ساير هيبريدها داشت البته عملكرد علوفه سيلويى آن در تاريخ كشت مب فروردين اندكى بيشتر از ساير تاريخهاى كشت بود ولى اين تفاوت از نظر آمارى معنىدار نبود. در منطقه ورامين، احتمالاً كشت سينگل كراس ل V0 و هيبريد ماكسيما نسبت به دو هيبريد ديخر از نظر عملكرد علوفه سيلويى ارجحيت دارد و بيشترين بروتئين علوفه نيز مربوط به هيبريد ماكسيما است كه اثبات قطعى آن نياز به تكرار آزمايش در سالهاى بيشترى دارد.
كشت در منطقه ورامين دربيشتر هيبريدها، ها ارديبهشت باشد كه از ساير تاريخ كشتها مساعدتر بوده است زيرا كه در اين تاريخ كاشت، هم دما براى سبز شدن نهال بذرها و رشد اوليه مساعد است و هم ساير مراحل حساس رشد گياه، به دماهاى خيلى بالا برخورد نكرده است. همخِنين با بررسى شاخصهاى رشدى كه مشخص شد كه در تاريخ كشت ها ارديبهشت، هيبريدها از نظر سرعت رشد نسبى، سرعت رشد گياه، سرعت جذب خالص و تجمع ماده خشك نسبت به ساير تاريخهاى كشت برترى داشتهاند و اين موضوع نشاندهنده مساعد بودن اين شرايط دمايى براى رشد است.

\section{منابع مورد استفاده}

1. Ahmadi, M., B. Kamkar, A. Soltani, A. Zeinali and R. Arabameri. 2010. The effect of planting date on duration of phonological phases in wheat cultivars and it's relation with grain yield. Journal of Plant Production Research 7(2): 109-122. (In Farsi).

2. Alilou, A. A., H. Fathi Ghooshieh and E. Mohamadi. 2012. The effect of sowing date and plant density on morphology, phenology and yield variables of maize hybrids in Bonab Region. Agricultural Science and Sustainable Production 22(2): 1-12. (In Farsi).

3. Almodares, A., M. Jafarinia and M. R. Hadi. 2009. The effect of nitrogen fertilizer on chemical compositions in corn and sweet sorghum. American Eurasian Journal of Agriculture and Environment Science 6: 441-446.

4. Amiri Deh Ahmadi1, S. R., M. Parsa, A. Nezami and A. Ganjeali. 2010. The Effects of Drought Stress at Different Phenological Stages on Morphological Traits and Yield Components of a Chickpea (Cicer arietinum L.) under Greenhouse Conditions. Iranian Journal of Field Crops Research 1(2): 68-84. (In Farsi).

5. Banaei, T. and M. Basafa. 2007. Investigation and Comparison of Final Yield in Silage Corn Hybrids. Final Report of Corn and Forage Crops Department. Seed and Plant Improvement Institute, Karaj, Iran. (In Farsi).

6. Blum, A. 2005. Drought resistance, water-use efficiency, and yield potential—are they compatible, dissonant, or mutually exclusive? Australian Journal of Agricultural Research 56: 1159-1168.

7. Choukan, R. and H. Hasanzadeh Moghadam. 2010. Heat units' requirenment of different maturing maize (Zea mays L.) hybrids based on thermal indices in Mashhad. Agroecology 2(2): 278-286. (In Farsi).

8. Choogan, R. 2004. Corn Production. Agriculture Research and Education Organization. Tehran, Iran.

9. Darby, M. H. and J. G. Lauer. 2002. Planting date and hybrid in fluence on corn forage. Canadian Agronomy Journal 98: 281-289.

10. Dehghanpour, Z. and A. Vahdat. 1996. Evaluating the combined effects of planting date and plant density on yield of maize silage in Mashhad. Seed and Plant 2: 30-35. (In Farsi).

11. Densley, R. J., G. M. Austin, I. D. Williams, R. Tsimba and G. O. Edmeades. 2006. Maize silage and winter crop options to maximise dry matter and energy for NZ dairy systems. Proceedings of the New Zealand Grassland Association 68: 193-197.

12. Emam, Y. 2007. Cereal Production. Shiraz University Press, Shiraz. (In Farsi).

13. Emam, Y. and M. Niknezhad. 2004. Introduction to Crop Yield Physiology. Shiraz University Press. Shiraz. (In Farsi).

14. Estakhr, A. and R. Chokan. 2006. Effect of planting date on grain yield and its components and reaction to important maize viruses in Fars province in some exotic and Iranian maize hybrids. Seed and Plant Production 22(2): 167-183. (In Farsi). 
15. Gardner, F. P., R. B. Pearce and R. L. Mitchell. 2003. Physiology of Crop Plants. Iowa: Iowa State University Press. Iowa.

16. Goldani, M. and P. Razavi Moghadam. 2006. Effects of different irrigation regimes and sowing date on growth and phenological characteristics of three varieties of dry land and irrigated in Mashhad. Journal of Agricultural Sciences and Natural Resources 14: 1-12. (In Farsi).

17. Halil, Y., M. Dasci and M. Tan. 2009. Evaluation of annual legumes and barley as sole crops and intercrop in spring frost conditions for animal feeding Yield and quality. Journal of Animal and Veterinary Advances 8(7): $1337-1342$.

18. Hall, A. E. 2001. Crop Responses to Environment. CRC Press. Boca Raton London New York Washington, D.C.

19. Karimi M. and M. Azizi. 1994. Growth Analysis of Crop Plants. Mashhad University Jihad. Mashhad.

20. Khodadadi, H. 2000. Effect of row spacing and planting date on yield of hybrid corn silage in Shahrekord. Seed and Plant 16: 52-65. (In Farsi).

21. Lithourgidis, A. S., I. B. Vasilakoglou, K. V. Ohima, C. A. Dordas and M. D. YIakoulaki. 2006. Forage yield and quality of common vetch mixtures with oat and triticale in two seeding ratios. Field Crops Research 99: $106-113$.

22. Lopez - Bellido, F. J., R. J. Lopez - Bellido, S. K. Khalil and L. Lopez - Bellido. 2008. Effect of planting date on winter kabuli chickpea growth and yield under rain fed Mediterranean conditions. Agronomy Journal 100: 957-964.

23. Mosavi, K., P. Pezshek Poor and M. Shahvardi. 2006. Effects of planting date, crop variety and weed interference on yield and yield components of dryland chickpea (Cicer arientinum L.). Iranian Journal of Field Crop Science 40: 167-176. (In Farsi).

24. Oktem, A., A. E. Oktem and Y. Coskun. 2004. Determination of sowing dates of sweet corn (Zea mays L. Saccharata sturt.) under Sanliurfa Conditions. Turkish Journal of Agriculture 28: 83-91.

25. Pessarakli, M. 2011. Hand Book of Plant and Crop Stress. 3 Edition. CRC Press. CRC Press. Madison Avenue, New York.

26. Rahmani, A., M. Nasrollah Alhossaini and S. Khavari Khorasani. 2014. Evaluation of sowing date, plant density and harvest method on growth a yield of salad maize (Zea maize L.). Iranian Journal of Field Crops Research 12(3): 526-534. (In Farsi).

27. Sadras, V. O. and D. F. Calderini. 2009. Crop Physiology, Applications for Genetic Improvement and Agronomy. Academic Press, USA.

28. Smith, D. L. and V. S. Hamel. 2005. Crop Yields, Physiology and Processes. Translation by Emam, Y. and M. J. Seghatoleslami. Shiraz University Press, Shiraz. (In Farsi)

29. Steinberg, C. E. W. 2012. Stress ecology, Environmental Stress as Ecological Driving Force and Key Player in Evolution. Springer Dordrecht Heidelberg, New York.

30. Van Soest, P. J. 1982. Nutritional Ecology of the Ruminant, OSB. Books, Inc. Corvallis, OR.

31. Ward, J. D., D. D. Redfearn, M. E. McCormick and G. J. Cuomo. 2001. Chemical composition, ensiling characteristics, and apparent digestibility of summer annual forage in a subtropical double cropping system with annual ryegrass. Journal of Dairy Science 84: 177-182.

32. Williams, M. M. and J. L. Lindquist. 2007. Influence of planting date and Weed interference on sweet corn growth and development. Agronomy Journal 99: 1066-1072. 


\title{
Evaluation of Growth Indices and Qualitative Traits of Maize Hybrids at Different Sowing Dates in Varamin, Iran
}

\author{
H. A. Karimzadeh Soureshjani ${ }^{1}$, M. R. Tadayon ${ }^{2 *}$, M. Shalalvand ${ }^{3}$ and Y. Fardi ${ }^{3}$
}

(Received: January 13-2018; Accepted: March 6-2018)

\begin{abstract}
In order to evaluate the suitability of maize hybrids in different planting dates, an experiment was conducted as split plot in JalilAbad, Varamin, Iran in 2015. Main and sub plots were planting date (D1: April 4, D2: April 19, D3: May 5, D4: May 20) and maize hybrids (H1: Gazda, H2: Maxima, H3: KSC 701, H4: AS160) respectively. Results indicated that there was variation between hybrids in terms of leaf area index (LAI), dry matter, crop growth rate (CGR), relative growth rate (RGR) and net assimilation rate (NAR) in different planting dates. Also results showed that the effects of planting date, hybrid and planting date $\times$ hybrid interaction on plant height, plant weight, ear weight, ear/plant weight ratio, silage yield and water use efficiency were significant. Among the qualitative traits examined, the effects of hybrid on protein and neutral detergent soluble fiber were significant. The best planting date for achieving the highest silage yield of hybrids Maxima and AS160 were May 5 and 20, but for KSC 701 was April 19 and May 5. However hybrid Gazda had a similar yield in all planting dates. It was concluded that even though cultivation of KSC701 and Maxima seems preferable in terms of silage yield but repeating this experiment in further years is necessary for a solid recommendation.
\end{abstract}

Keywords: Growth Analysis, Protein, Water Use Efficiency

1. Researcher of Crop Physiology, Etka Research and Innovation Center, Tehran, Iran.

2. Associate Professor, Department of Agronomy and Plant Breeding, Faculty of Agriculture, Shahrekord University, Shahrekord, Iran,

3. MSc. in Agronomy, Iranian Modern Farms, Tehran, Iran.

*: Corresponding Author, Email: mrtadayon@yahoo.com 